\title{
Force in Nature, Freedom in History. Hegel and the neo-spinozistic project of a Natural Human History
}

\section{Fuerza en la naturaleza, libertad en la historia. Hegel y el proyecto neo-spinozista de una historia humana natural}

RESUMEN: En esta contribución se explican las conexiones entre las líneas alemanas de la recepción de la Ethica y del Tractatus TeológicoPoliticus y la formación de las Filosofías de la Historia de Herder, Schelling y Hegel. En este estudio, se indica a la Filosofía de la Unidad como una corriente principal, pero se articulan las líneas de la recepción de la Ethica con las dificultades procedentes de las explicaciones en el Tractatus de Spinoza para la multiplicidad de las tradiciones religiosas, como formas históricas divergentes de percibir el Uno. Las Lecciones de Hegel sobre Filosofía de la Religión fueran examinadas desde la perspectiva de su significado metódico general y también desde el punto de vista descriptivo. Aquí se encuentran las claves fundamentales para la comprensión de la perspectiva del filósofo con respecto al valor de Spinoza para el método especulativo y en la caracterización de las épocas en la Historia de las Religiones Bíblicas. La crítica de Hegel a la Filosofía de la Unidad personificada en la

\begin{abstract}
This contribution explains the connections between the German lines of the reception of the Ethica and the Tractatus Theologico-Politicus and the formation of Herder's, Schelling's and Hegel's Philosophies of History. It refers to the Philosophy of Unity as a main current but articulates the lines of the reception of the Ethica with the difficulties raised by Spinoza's explanations for the multiplicity of the religious traditions, as divergent historical ways to the One, in the Tractatus. Hegel's Lectures on Philosophy of Religion were scrutinized from the angle of their general methodical significance and also from the descriptive point of view. Here, one finds critical keys for the understanding of the philosopher's perspective regarding Spinoza's meaning to the speculative method and for the characterisation of the epochs in the History of the Biblical Religions. Hegel's critique of the Philosophy of Unity personified in Schell-
\end{abstract}


apropiación en Schelling del conatus de Spinoza fue retratada con el intento de localizar el núcleo de la idea de una homogénea Historia Natural y Humana. El texto aboga que en la crítica por Hegel del Espinosismo de Schelling se admitirán las líneas alemanas de recepción de Spinoza como las responsables de un concepto vago de lo Absoluto. Tal indeterminación explica la ausencia de claridad sobre la diferencia entre la Naturaleza y el Espíritu (Historia), en particular en el Absoluto de Schelling, y exige una configuración distinta de las «Filosofías Reales» en el sistema filosófico.

PALABRAS CLAVE: FILOSOFÍA DE LA HISTORIA - FILOSOFÍA DE LA NATURALEZA - FILOSOFÍA DE LA RELIGIÓN - CONATUS - IMPPETU - DIVERSIDAD RELIGIOSA - NATURALEZA - ESPÍRITU - SPINOZA; -HERDER - SCHELLING - HEGEL. ing's appropriation of Spinoza's conatus was envisaged in order to locate the pivotal point of the idea of an unbroken Natural and Human History. The paper argues that in Hegel's critique of Schelling's Spinozism the German lines of Spinoza's reception were taken as responsible for a vague concept of the Absolute. Such vagueness explains the absence of clarity about the difference between Nature and Spirit (History), particularly in Schelling's Absolute, and demands a different configuration of the «Real Philosophies» in the philosophical system. KEY WORDS: PHILOSOPHY OF HISTORY - PHILOSOPHY OF NATURE - PHILOSOPHY OF RELIGION - CONATUS - FORCE - RELIGIOUS DIVERSITY - NATURE - SPIRIT - SPINOZA; HERDER - SCHELLING - HEGEL.

\section{LINES OF SPINOZA's GeRMAN RECEPTION AND THE EXEGETICAL CHAL- Lenges of the ReAding of the Tractatus Theologico-Politicus}

Tn the larger European context, Spinoza's understanding of the History of the Biblical Religions in the Tractatus Theologico-Politicus is a turning point in the evolution of the concept of a Universal History from the inside of the theological vision of the History of Human Salvation, linking Creation, Revelation and Redemption. Along this development, the concept of History undergoes significant confrontations, facing the religious crisis, the impact of the scientific image of Nature and natural causation and the impressions caused by the findings attesting the human diversity on Earth as a consequence of the $16^{\text {th }}$ Century Maritime Discoveries. In the $17^{\text {th }}$ Century, many signs of these confrontation lines are easy to follow in the diverse expressions of the political and religious learned writings on "Conjectural History" or in the speculations of the naturalists about the place of Man in the course of Nature's epochs.

I'll consider three main lines across the particular reception of Spinoza's Philosophy in Germany, in the $18^{\text {th }}$ Century ${ }^{1}$. A first line, which was mainly

[1] Recent studies on the formation and the internal variety of the European Enlightenment 
concerned with the meaning of the "En kai Pan" and Pantheism; a second direction dealing with the Faculties of the Soul, the importance of affection, feeling and emotions in Human Knowledge and a third line dedicated to the application of the "Philosophy of Unity" of Spinoza's Ethica to History. These three lines evolved since the 1780's, namely with Jacobi, Lessing, Goethe, Mendelssohn and Herder. A new generation represented by Scheling, Hölderlin, I. von Sinclair, Molitor and Hegel came ten years later. In 1795, in Hegel's correspondence with his Tübingen friends (Schelling and Hölderlin) the importance of the study of Spinoza's Philosophy is already evident (Hegel: 1969, 21-22).

F. Schlegel's Transcendental Philosophy (1800-01) was a project inspired in Spinoza's Philosophy of Unity and pointing to a new Philosophy of Life conceived as the solution for the limitations of the Kantian transcendental Philosophy. F. Schlegel's endeavour with his concepts of organism, totality and unification of the separations shows what kind of philosophical concerns guided the new generation in the reading of Spinoza, but also reveals a preference in the choice of Spinoza's texts. Indeed, in this early attempt F. Schlegel takes mainly the Ethica and the Treatise on the Improvement of the Understanding but not the Tractatus. Such preference is common to those who read Spinoza through the Ethica, the intellectuals that read only De Deo, the first book of the Ethica, or the authors that knew Spinoza through P. Bayle's article in the Dictionnaire... Hegel's views on Spinoza in the period of Berlin are deeply connected to the maturation and final expression of the German reception and especially to Schelling's appropriation in his Philosophy of Identity.

\section{1. The Historicity of the Revelation in the Tractatus Theologico- Politicus and the "Philosophy of Unity" of the De Deo}

The Tractatus embodies a dualistic explanation of the religious Biblical revelation and keeps the fundamental metaphysical dualisms (namely the opposition thought - matter / mind - body) according to a precise theoretical purpose, metaphysical, political and religious. The dualisms refer to basic distinctions that support the narrative on the History of the Revelation from Judaism to Christianity. The metaphysical distinctions are underpinnings of the Biblical differences between the Jews and the Christians and the substructures of the distinction between politics and religion. In the Tractatus, discussing the meaning of the subject of the Biblical Revelation Spinoza opposed God according to the Natural Light to God as Lord of the World.

have conceded to the link of "spinozism" to the "libertines" in the Dutch Republic an increasing seminal importance (See: Wielema: 2004; IsRael: 2006). In this paper, I'll abstract from these sources of Spinoza's portrait to concentrate the focus on the German currents. 
The systematic and the descriptive meanings of these distinctions are connected across the critical explanations of the Tractatus regarding the value of the Biblical narratives, from the Ancient to the New Testament. The political dimension of the Revelation is disclosed in the State's most important aim - the conservation of peace and security - through ceremonial rules. On the other hand, the Eternal Laws conceived by Natural Reason don't have a direct normative influence in civil society and they are independent from History. God's Revelation to the Jews added to the Eternal Laws of Nature the knowledge of the rules of the civil society and the religious ceremonials, but according to the particularity of the alliance with Israel and the Election of the Jews. Spinoza's Tractatus continuously deals with the value of the universality that is eternal but faces the concrete universality of the religious-political life of a People evolving from the multitude to the concept of a unique Mankind, through History. Thus, the Christian proclamation of a universal Love resembles the Amor Dei intellectualis of the Ethica but according to an imperfect image. The reasons for the imperfection are historical - they were generated in the History of Revelation itself, in the division between state and religion; the particularity of the Election of the Jews and Christianity; ${ }^{2}$ the multitude and the rational, emancipated man. Spinoza confers to the Christ the power to transcend the particularity of the ceremonial rules and precepts of the Jewish Torah. But, the apparent universality of the Christian Love to Mankind must face its own historical emergence from Judaism and its difference regarding the political life. It is a universality submitted to time and to difference.

Consequently, it is not possible to find in the Tractatus a view on the unity of Reason and Revelation, the Amor Dei intellectualis, transcending the divide between the Jews and the Christians, State and Religion. The Philosophy of Unity of the Ethica has not the same systematic articulation as the historical, genetic descriptions of the Tractatus.

Can one claim that the Philosophy of Unity of the Ethica is like a hypothesis that the History of the Biblical Religion of the Tractatus confirms through the concrete evolution of the political and religious institutions and always through the difference of the religious and the political?

If this seems promising, Spinoza didn't conclude the exploration of the way to the unity of the substance across the historical-biblical Hermeneutic of the History of Religion. This explains Hegel's remarks about the absence of a historical-speculative view in Spinoza's concept of substance and consequently

[2] In his studies on Spinoza, Leo Strauss referred already the context of the formation of Spinoza's idea of an "History of Salvation", facing the upshots of the socinianism, the image of Uriel da Costa and particularly La Peyrère's Historiosophical speculations (see STRAUSs: 1996, 34-86). 
his repudiation of Spinoza's more geometrico methodical procedure and intellectualist abstraction.

If the Eternal Laws are the rules of God's eternal production of Nature acknowledged by Reason, there is nothing equivalent to an immediate expression of God's productivity in the historical events or in the human understanding of the political and religious causation through faith, sensation, imagination or fictional narratives. In the case of Spinoza's Philosophy this means that the distinction between Nature and History must be addressed separately, even incurring the risk of a final decision in favour of the unavoidable irrationality of the historical course.

One of the clearest theses in the Tractatus states the impossibility of a monist point of view regarding Philosophy of Nature and Philosophy of History. Here, Spinoza says that the nations are not "by nature", only the individuals are "by nature": "Nature doesn't create nations, but individuals".

I'll argue that it was this division line between Nature and History the forgotten theoretical issue along the mainstream of the German's reception of Spinoza, before Hegel. Partly due to the importance of the Philosophy of Unity of the Ethica and the reduced assessment to the Tractatus the difference between Nature and History as an ontological and epistemological theme was almost erased from Herder's, Molitor's or Schelling's evaluations of Spinoza. The imagination of an anthropological continuum was a major consequence of the application of the principles of the Philosophy of the Unity to the "ethical life" and to History. Hegel will recuperate the gap between the Ethica and the Tractatus, Nature and History, as a problem to be solved in the context of the discussion of the systematic unity of Philosophy, which the final state of the German Spinozism in Schelling's "Philosophy of Identity" (or synthesis between "negative" and "positive Philosophy") didn't offer.

I. 2. NATURE AS EXPANSION OF FORCES AND the IDEAL OF a NATURAL Human HISTORY - ALONG THE THIRD LINE OF THE GERMAN RECEPTION OF SPINOZA

\section{2. 1. HERDER}

The enthusiasm regarding Spinoza among the group of Hegel's friends in Tübingen, Schelling and Hölderlin, is documented by two letters from Schelling to Hegel and from Hölderlin to Hegel, both dated 1795. Along the 1800's it was F. J. Molitor the representative of a serious theoretical effort in the conception of a Natural Human History according to an interpretation of Spinoza's Philosophy of Unity. But Herder's Ideas about the Philosophy of History of Mankind (1784-91) anticipated Molitor's sketches. Here, the notions of organism and life 
came to the foreground of a general concept of Nature, which was intended to include also History and Anthropology.

In his Ideas, Herder extended the former essay Auch eine Philosophie der Geschichte (1774). Such project is a direct application of the Philosophy of Unity to Nature and to History, achieving the ideal of the Unity of Nature and Mankind, endangered in the Kantian precautions regarding the limits of the Human legitimate knowledge. The concept of force that Herder converted from Leibniz and the principle of a "unity of the organic composition" from G. de Saint-Hilaire (1795) serve the grandiose purpose of the Human Natural History. In the dialogue Gott Herder envisaged the organic force as an apt translation for Spinoza's ideas of conatus and natura naturans. In this text, the metaphor of the organism and the concept of expression suggested both the way Nature operates throughout all its creations according to a symbolic relation ruling the co-reference of the whole and the parts, complementing Leibniz with Spinoza. The speculations about the unity of the organic composition and the views on the principles of the nature's morphogenesis also occurred in the epoch in Goethe's morphological essays until the 1807 text Bildung und Umbildung organischen Naturen, under Spinoza's palpable inspiration.

According to Herder's Ideas, the human inner organization with its sensitive structure is adapted to a force that comes from the Earth as a living complex organization made of interdependent parts. Each individual being owes to the Earth's organization its own morphology and functional capabilities (Herder: 1785 - I, 7-8). The internal principle that rules the human's life is a modification of the same force that animates the larger cosmos. Herder transformed the ancient views on Human Nature and the bodily humors of the Hippocratic Corpus, including the use of the concept of "culture", adapting to his theoretical needs the anthropological-geological continuum. The human singularity among the innumerable parts of the Earth's organism represents a force among a system of forces: eine Kraft im System aller Kräfte (Herder: 1785 - I, 9). Such eclectic conclusion modifies Spinoza's substance as natura naturans in an intelligent organism similar to the neo-platonic World-Soul.

The congruent relation between the multiplicity and the unity in the actual world is an effect of the concrete subordination of the partial drives of the singular parts to the whole's drive, as conveyed in the sentiments of the sentient beings. Even if Herder's theory of the sentiment was a resultant of other influences, it was also an heir of Spinoza's rehabilitation of affectivity.

Supporting his views on Buffon's Les Époques de la Nature Herder mentions a Geogenesis of Human Nature (Herder: 1785, 20). Across this Geogenesis is described an historical process whereby a series of beings comes into existence only if previous series made the scene. Nature's inner hierarchical organization 
and epochal sequences are possible through a scale of beings and epochs, which have their zenith in Mankind as the Microcosmos and across Human History. The philosophical perspective on Natural History combines empirical historical data with a speculative view on the continuity of Life and the Geological epochs. This fictional synthesis justifies the impressive proclamation about die Erde als ein Schauplatz der Menschengeschichte (Herder: 1785 - I, 56) and the use of "culture" to refer the anthropological dimension in this Natural History (Herder: 1785 - I, 93-94).

Analogously to Goethe's morphological speculations Herder conceived the external variety in the organization of the natural species as an expressive variation of the inner productive force of Life. The internal forces of Nature communicate through organs responsible for the exteriorization in the phenomenal forms of the outer world. A comment on the hypothesis of Epigenesis, the use of Bildung to conceptualize the expressive formations of the forces and the inclusion of the political communities or nations among the forces's productions occur naturally in this context (Herder: 1785 - II, 153).

A symptom of the importance of Spinoza's reception through Herder's writings in Germany is Kant's reaction to the Ideas. Kant's core critique is directed against the speculative character of the assumption of a uniform organism coupling Natural and Human History, which was the main consequence of the Philosophy of Unity ( $c f$. Zammito: 1997, 122-123). Besides, Kant's critical review of Herder's book is perfectly aligned with the critique of Spinoza in the $\$ 75$ of the Kritik der Urteilskraft.

\section{2. 2. F. J. MOLITOR}

Avoiding a direct mention to Spinoza, but approving the unity of Nature and History as the outcome of the inner productivity of conscious and unconscious forces, in a book on the "dynamic of History", Ideen zur einer künftigen Dynamik der Geschichte (1805), F. J. Molitor, a philosopher interested in the Kabbalah and Schelling's correspondent (Koch: 2006), formulated his thesis about a "game of forces", underlying the phenomenal temporal processes, basically structured over two polarities - the eductive and the expansive forces. History was conceived as a provisional resolution of the structural tension opposing the two principles, where it is impossible to situate a final "point of absolute indifference" but only relative equilibria. What is perceptible in History has an equivalent in Nature. It is correct to apply to both the same notion of an infinite productivity of beings and forms. Ceaseless, everything is product and productivity - Eins in Allem und alles in Einem (Molitor: 1805, 44). The unity of the Human History and the Natural History corresponds to a "whole-universe" and this is the true foundation of a Universal History. 
Through the Universal History the spectacle of the creation and destruction of epochs is analogous of the generation and death of living beings. Each historical period and peoples are like individualized expressive forms of the two ruling forces, the expansive, subjective and positive and the eductive, objective and negative. The eductive force explains the finite character of the historical phenomena, their particular complexion. The expansive principle is like a subjective drive of the temporal movement (Molitor: 1805, 62-63). The two great epochs of the Universal History are the Ancient and the Modern. The Ancient represents the productive force, the subjective, and the Modern the eductive, objective.

F. J. Molitor thought also that both epochs were relatively autonomous, even if the History evolves from the Ancient to the Modern, like a move from the unity to the difference, the subjective concentration of the force towards its division and dispersion. Thus, the Human History is comparable to a process of self-division of the unity or to a temporal dispersion of the natura naturans into the multiplicity of the natura naturata.

\section{2. 3. SCHELLING}

In Schelling's work the Absolute was historically conceived. This general impression is confirmed in detail through the analysis of the Philosophy of Mythology and the Philosophy of Revelation. In both works, the themes of the Philosophy of History were addressed according to some conventional topics and also preserving the analytical sequence of the historical periods of Spinoza's Tractatus, Paganism, Judaism, and Christianity, assuming the Biblical History as the prototype of the Universal History. The internal articulation between both works (Mythology and Revelation) unveils a Speculative System of History based on the underlying agreement between History and Bible's narration or between Historical Hermeneutics and Biblical Hermeneutics.

In the Philosophy of Revelation, Schelling deepened the distinction between "negative" and "positive" Philosophy and positioned his system regarding Spinoza, Kant, Fichte and Hegel.

"Negative" and "positive" refer to a distinction in the philosophical approaches that entails, on one hand, a thought that relies on a reference to something different from itself (negative principle) and on the other hand the positive principle, that asserts the identity of the thought and the object. Negative Philosophy accepts the price of the platonic parricide against Parmenides and combines in thought, being with non-being, difference and potentiality with the actuality of the thought. This thinking in the realm of difference is a combination of knowing with non-knowing, which Schelling calls empirical and identifies with Kant's transcendental method. Contrariwise, the realm of 
pure thinking free from any reference to alterity is also independent from the empirical content. This freedom is equivalent to the Aristotelian "energeia", to the platonic knowing of the "pantelous on" or to positive Philosophy.

If the pure thought is apprehended as an act independent of content and conceived as the real source of the objectivity we are facing the roots of the philosophical perspectives of Spinoza, Fichte or Hegel. According to Schelling, the real final end of Philosophy is to become positive Philosophy. The negative moment is relative, provisional and conditional. But the difficult task of the philosophical thinking is the recognition of the balance and unity between the negative and the positive poles. The positive represents the emancipation from the contingency and is identified with Freedom. If Spinoza is a symbol of the positive principle in Philosophy (Schelling: 1858, 157), the author of the Ethica didn't acknowledge the role of the other principle ${ }^{3}$.

In the Philosophy of Revelation Schelling started with the identification of the two poles of the History of Mankind - State and Religion. He was also concerned with the demonstration of the continuity between the History of Nature and the History of Mankind, which is noticeable in the passage from Mythology to Monotheism in the Human Religious History. His analytical scheme for the understanding of a self-divided unity can be portrayed in the formula Force in Nature and Freedom in History.

Discussing the meaning of Christianity in the History of Religion Schelling developed a double concept of History. The historicity of Christianity is not grasped along the external sequences of events connected to its founder's biography or to the Political History of the epoch. Such mode of signifying History corresponds to the empirical, negative methodology. The "highest historicity" consists in the self-development of God discovering itself as the only God and as one with its Son. In the historical self-revelation of the unique God is disclosed the same structure that relates the negative and the positive in Philosophy; nature and spirit. It is in Christianity that the meaning of the historical process comes to its truth; not only as an episode in the religious narratives of miracles but essentially as a meta-event that links God to Mankind and the Nature's Creation to a meaningful Revelation of the God becoming Man.

The Christian message regarding a unification of the Human species under the Kingdom of God was announced in the Religion of Mysteries, as the Nature's secret to be proclaimed at the end of History. From the initial announcement to the eschatological accomplishment a course evolves from the inside to the outside; from the secret to the manifest in accordance with the transformation of matter in spirit, the particular in universal, the coerced in the free. Schelling

[3] Spinoza ist insofern auf den tiefsten Grund aller positive Philosophie gekommen, aber sein Fehler ist, daß er von diesem aus nicht fortzuschreiten wusste (ScHELLING: 1858, 157). 
conceives these motions as discharges of a drive (Triebkraft) innate in the living Nature (Schelling: 1858, 528) and responsible for the gradual transformation of Nature in History. The worth conceded to the inner force justifies not only the fascination with the unconscious but the thesis about the actus of the potentiality (noch nicht Seyende) in the temporal processes (Schelling: 1858, 212), as an internal propulsion of Nature and History, similar to Molitor's subjective force or to Spinoza's natura naturans.

\section{Hegel's Concept of the Autonomy of History and the motto “The One is the Whole" in his Philosophy of Religion}

Under the general principle of the realization of Freedom through History, Hegel developed along his Berlin Lectures on Philosophy of Law, Philosophy of History and Philosophy of Religion a concept of History occasioning a confrontation with Spinoza, especially in this last collection of Lectures. Summarizing, Hegel concedes that Spinoza understood the need for the rejection of the metaphysical dualism but criticized the fact that his concept of substance had an "abstract character", because it is not possible to follow through concrete determinations the dialectic relation of essence and existence in the concept of God. Spinoza's substance discloses one of the aspects of the self-determination of the Concept but is not totally identical with the Concept. The methodological recommendation of the Phenomenology of Spirit to convert the substance in the subject and the subject in the substance would be impossible according to Spinoza's own understanding of the Absolute as God's immobile substance. Hegel's views about Spinoza in the Lectures on the History of Philosophy maintained the same ambivalence and expressed the characteristic way of the philosopher's approach to the Spinoza's substance, defined as a typical creation of the Verstand. The Lectures About the Proofs of the Existence of God, particularly the $16^{\text {th }}$ Lecture (1829), reveal a similar attitude. Here, the discussion is focused on the meaning of the causa sui and in the interpretation of the notions of cause and effect, with the purpose of the demonstration of the abstract (intellectual) use of these notions in Spinoza's definition of the substance. The references to Jacobi and to his role in the critical reception and a comparison between Spinoza and Parmenides attest the closeness of these Lectures to the texts in the group of Lectures on Philosophy of Religion.

In the Lectures on Philosophy of Religion Hegel's diagnosis of Spinoza's limitations led to the subordination of "pantheism" to a moment in the selfdetermination of the Concept of Religion, contrasting with the uncritical enthusiastic acceptation of the "En kai Pan" in the reception line of Herder, F. Schlegel, Molitor or Schelling. The way Hegel correlated essence and existence in the Berlin Lectures relies on the understanding of the logical categories (of 
the Logic of Essence) and on their application to the Real Philosophies (Nature and Spirit). It is across the logico-real uses of the categories of essence and existence that Hegel differentiates the various solutions (pantheism is one) to the problem of the relation of the unity of the substance to the empirical differences or manifestations.

In the Philosophy of Religion discussing the "En kai Pan" and the meaning of pantheism, Spinoza's understanding of the relation of the essence to existence was depicted as an abstract, unconscious, blind power inherent to the finite beings but disconnected from a proper, dynamic relation with the Absolute. Continuing his appraisal, Hegel saw in the Ethica's way to pantheism traits similar to the worldview of the Oriental Religion. The moral indifferentism is a consequence that legitimately follows.

The most important critical argument Hegel uses against Spinoza and Schelling's "Philosophy of Identity" states that both philosophers conceived the "En kai Pan" as a blind productive force without content, both detached the power of the substance from the knowing of its concrete contents. Consequently, Spinoza's substance cannot be a knowing subject. It is such non-subjective, nonspiritual character of the substance that explains its family resemblance with the oriental principles regarding the influence of the Divine in the finite existence.

Hegel's critical explanation of the divorce between the Will and the Knowledge, the drive and the concrete determinations of Spinoza's substance puts at risk the plan to convert the Philosophy of Unity of the Ethica in the metaphysical foundation of both Real Philosophies and of the Philosophy of History. But this was precisely the aim of Spinoza's sympathetic line of reception in Germany along the $18^{\text {th }}$ Century, including Schelling. On the other hand, the placement of Spinoza's substance at the same side of the worldviews of the Oriental Religion also reveals the incompatibility of the Philosophy of Unity with Christianity, a critical consequence Hegel infers, which is only similar in its immediate appearance to Jacobi's critique of Spinoza.

Hegel's evaluation of Spinoza in the Philosophy of Religion unveils the problem of the consistency between the method of the Ethica (unity of substance) and the descriptive content of the Tractatus (concrete historical determinations), which Spinoza didn't address properly and Herder or Schelling simply ignored. They disregarded the theoretical difficulties of a direct application of the mixed concept of a force-substance to epochal, ethical-religious determinations without the consideration of the real activity of knowing across the concrete historical events. But without the process and the contents of an historical knowing there is no recognizable force and a force that is unrecognizable cannot be defined or referred. 
In the 1824 version of the Lectures on Philosophy of Religion, in the notes on "immediate Religion", division A. a) "metaphysical concept", Hegel reassessed Jacobi's identification of the Spinozism with pantheism and concluded that "pantheism" was ascribed vaguely to many philosophical and religious doctrines using the words Being, Dasein, finite, infinite, "each" and "whole" that excluded the mediation of Thought or Knowing. The essential motive of Hegel's resistance regarding the German reception line of Spinoza becomes sharper when he assumes that the absence of a concept of mediation of Being and Thought is here the unforgivable mistake. "Pantheism" means that God or the infinite is manifest in each finite being as a reason to be: Dies Dasein enthählt in sich das Sein, und dies Sein im Dasein, das ist Gott. But, how can one distinguish between this "pantheism" and Parmenides's thesis that only the Being is? According to both views (pantheism and Parmenides) Being and being determinate are separate things, immediately confronting each other, but only to conclude afterwards that they are identical, as if their relation were the same as the content and the container".

"Pantheism" means truly the thesis that God is in the totality of beings only if one recognizes God along the progression of the thought about this finite existence. Thought is the unique medium of the self-explanation of God's manifestation. Spinoza's concept of the substance's modi and the distinction between the substance in itself and the modi are not satisfactory means to give a proper picture of the relation of the totality of the finite beings and the unique substance. This is the justification for Hegel's final critical judgement, which affects not only Spinoza but also the German reception: Spinoza's substance means the affirmation of God in the empirical existence as an empty power (Macht). It is not irrelevant the use of the concept of power in the context. It represents the potency of the non-mediated. The trouble arising from the representation of this power, force or potency is precisely the absence of its concrete application, which is a proof of the abstract separation of the Will from the Knowledge. But, if a power without concrete application is powerless, it is because there is no such thing as a non-mediated power or a will without knowledge. The reason for the use of the concept of force as an all-purpose concept applying to Nature and to History, indifferently, is now clear. The pure affirmation of the presence of God in the empirical existence, as a power, such empty identification, is the unique valid definition of this "pantheism". Thus, underlying the unity of the natural and the historical determinations, of force in Nature and freedom in History, of the modern pantheism, is the idea of an abstract power, without

[4] In the Lectures on Philosophy of History, Hegel enlarged the depth of the comparison of Spinoza's substance to the Chinese, Indian, Eleatic, Pythagorean and the general principles of the modern Metaphysics (Hegel: 1994, 175). 
subject or content, and a religious view, which is impossible to conciliate with Christianity. Hegel called this force or power "unfree Freedom", precisely because it represents the separation of the Will and the Knowledge.

A further inference from these premises of the philosopher's interpretation of Spinoza's "En kai Pan", as the abstract power facing the concrete reality and independent of the thinking mediation, is the political consequence. Hegel conceives the Spinozistic pantheism as a modern philosophical envelope of worldviews akin to the Oriental Religion and, with some adaptations, to the oriental political despotism or Theocracy, the extreme type of the unlimited sovereignty that extracts the rule of the State exclusively from the arbitrary will of the sovereign as this natural individuum ${ }^{5}$. In the 1824 and 1827 versions of the Lectures the parallel between Oriental Religion (especially the Brahmanism of the "Religion of Phantasy" and those determinations common to the Brahmanism and Judaism), and Spinoza is an ingenious way to save the partial truth of the doctrine of the Ethica, placing it in the evolution of the religious consciousness.

Through the integration of Spinoza's substance in the frame of his own Philosophy of the History of Religion, Hegel gave an interpretative key to his relation to Spinoza and an unexpected orientation in the conundrum of the articulation of the Ethica with the Tractatus. Additionally, his critical approach to Schelling's Philosophy of Identity as the achieved expression of the German Spinozism shows very well that Hegel begins his idea of the concrete historical precisely in the point where the German views on the "En kai Pan" stopped. Spinoza's substance gave the urge to the Dialectic concept of History. In Hegel's views speculative thinking and concrete historical thinking are two aspects of the same medal, but not like in Schelling's representation.

From these premises one can now conclude. Hegel refused a homogenous intellectual principle indifferently applied to Nature and History, exemplified in the concept of force as an heir of the German eclectic reception of Spinoza. The Absolute really operating in History owes its productivity to the concrete determinations of the Concept in the dialectic of the essence and existence

[5] With a slight correction to the prior equivalence between Spinoza's views and the oriental views, Hegel wrote his famous thesis about the oriental despot: Dies ist das Prinzip der orientalischen Welt, daß die Individuen noch nicht ihre subjektiven Freiheit in sich gewonnen haben, sondern sich als Akzzidenzen an der Substanz halten, die aber nicht eine abstrakte Substanz ist, wie die Spinozas, sondern Präsenz hat für das natürliche Bewußtsein in der Weise eines Oberhauptes, daß sie alles nur ihm angehörig sehen... Wir können in der orientalischen Welt die Herrschaft eine Theokratie nennen. Gott ist weltlicher Regent, und der weltlicher Regent ist Gott (HeGEL: 1994, 246). The oriental despot represents the concrete productive force of the substance according to its natural, individual manifestation. 
and not to a blind impetus abstractly defined and identified with God. Hegel's proposal entails a logical differentiation between the two Real Philosophies with consequences in the coherence of the philosophical system.

Nature is not yet Spirit. The development of this thesis in the context of Hegel's Philosophy of Law explains the radical rejection of the naturalism of "Natural Law" and the ideas about a "natural state of Mankind" as valid hypothesis for the study of the beginnings of Human History. It is not sufficient to say that there are two real dimensions of the manifestation of the Concept, Nature and Spirit (History), Force and Freedom. Hegel went much further, substantiating the thesis historically, showing that Freedom in History entails a gradual and epochal differentiation process of History itself from Nature. If Hegel achieved this purpose, then Schelling's critique of his former friend in the Philosophy of Revelation misses the mark and turns against him (Schelling: 1858, 204). Additionally, the statement Nature is not yet Spirit suspends the naïve views on an anthropological continuum.

Later, the Dialectical solution for the problem of the relation between the concrete historical sequences and a principle of speculative unity will put the Hegelianism in confrontation with Positivism and, lastly, the philosophical view on History in tense dialogue with modern Historiography.

\section{REFERENCES}

Bayle, Pierre. 17153. "Spinoza" in Idem, Dictionaire Historique et Critique Vol. III, N-Z, pp. 610-631. Rotterdam.

Goethe, J. Wolfgang. 2002. Werke. Naturwissenschaftliche Schriften I. Hamburger Ausgabe. Vol. 13. München: Verlag C. H. Beck.

HegeL, G. W. Friedrich. 1969. Briefe von and und an Hegel - 1 - 1785-1812. Hamburg: Felix Meiner.

Idem. 1986. Vorlesungen über die Geschichte der Philosophie. Vol. 4. Philosophie des Mittelalters und der neueren Zeit. Hamburg: Felix Meiner.

Idem. 1993. Vorlesungen über die Philosophie der Religion. Einleitung - Der Begriff der Religion. Hamburg: Felix Meiner.

Idem. 1993. Vorlesungen über die Geschichte der Philosophie. Einleitung. Orientalische Philosophie. Hamburg: Felix Meiner.

Idem. 1994. Vorlesungen über die Philosophie der Religion. Die bestimmte Religion. Hamburg: Felix Meiner. 
Idem. 1994. Vorlesungen über die Philosophie der Weltgeschichte 1. Die Vernunft in der Geschichte. Hamburg: Felix Meiner.

Herder, J. Gottfried. 1785. Ideen zur Philosophie der Geschichte der Menschheit. Vols. 1-2, Riga und Leipzig: Johann Friedrich Hartknoch.

Idem. 1799. Eine Metakritik zur Kritik der reinen Vernunft. Leipzig: Johann Friedrich Hartknoch.

Idem. 1800. Gott. Einige Gespräche über Spinoza's System, nebst Shaftesburi's Naturhymnus ${ }^{2}$. Gotha: Karl Wilhelm Ettinger.

Idem. 1990. Auch eine Philosophie der Geschichte zur Bildung der Menschheit. Stuttgart: Reclam.

Israel, Jonathan. 2006. Enlightenment Contested: Philosophy, Modernity, and the Emancipation of Man, 1670-1752. Oxford / New York: Oxford University Press.

Jacoвi, F. Heinrich. 2013. Über die Lehre des Spinoza in Briefen an den Herrn Moses Mendelssohn, North Charleston: Create Space Ind. Publish.

KocH, Katharina. 2006. Franz Joseph Molitor und die jüdische Tradition. Studien zu den kabbalistischen Quellen der "Philosophie der Geschichte". Berlin, New York.

KosLowski, Peter. 2005. The Discovery of Historicity in German Idealism and Historism (Ed.). Berlin, Heidelberg, New York: Springer.

MolitoR, J. Franz. 1805. Ideen zur einer künftigen Dynamik der Geschichte. Frankfurt am Main: Bernhard Körner.

Schelling, F. W. Joseph. 1857. Sämmtliche Werke. Zweithe Abt., 2. Philosophie der Mythologie. Stuttgart, Augsburg: J. G. Gotta'scher Verlag.

Idem. 1858. Sämmtliche Werke. Zweithe Abt., 3-4. Philosophie der Offenbarung. Stuttgart, Augsburg: J. G. Gotta'scher Verlag.

Schlegel, Friedrich. 1991. Transcendentalphilosophie. Hamburg: Felix Meiner.

SpinozA, Baruch. 1983. Ethica / Éthique. Texte Latin, Traduction nouvelle par C. Appuhn. Paris: Librarie Philosophique J. Vrin

Idem. 1999. Tractatus Theologico-Politicus / Traité Théologique et Politique in Idem, Oeuvres. Vol. III. Paris: P. U. F.

Strauss, Leo. 1996. La Critique de la Religion chez Spinoza. Paris: CERF

WAibel, Violetta. 2012. Spinoza - Affektenlehre und Amor Dei intellectualis (Hrsg.). Hamburg: Felix Meiner 2012.

Wielema, Michiel. 2004. The March of the Libertines. Spinozists and the Dutch Reformed Church (1660-1750). Hilversum: Uitgeverij Verloren. 
Zамmiтo, John. 1997. "Herder, Kant, Spinoza und die Ursprünge des deutschen Idealismus" in Marion, Heinz (Hrsg.), Herder und die Philosophie des deutschen Idealismus. Fichte Studien Supplementa. Amsterdam, Atlanta, GA: Rodopi B. V., pp. 107-144.

Edmundo Balsemão Pires is Professor of Philosophy at the University of Coimbra, Portugal

Research Interests: Social and Political Philosophy, Systems Theory, Ethics and Aesthetics, Hegel, German Idealism and Luhmann.

\section{AdDress:}

Largo da Porta Férrea 3004-530

Coimbra, Portugal

edbalsemao@icloud.com

Recent Publications:

- «Second Order Ethics» in Uncanny Journal - Philosophy and Cultural Studies Journal (2015), pp. 31-60.

- «A Arte da Estética» in Biblos, vol. XI (2014), pp. 121-184.

- «A Individuação dos Sistemas Psíquicos» in DEDiCA - Revista de Educação e Humanidades, nº 4, Março (Granada / Coimbra 2013), pp. 13-54.

- «Laic State and Revelation: a Political Reading of Rosenzweig and Levinas» in Rosenzweig Jahrbuch / Rosenzweig Yearbook 7 (Freiburg / München 2013) pp. 204-221.

- «The Epistemological Meaning of N. Luhmann's Critique of Classical Ontology» in Systems. Connecting Matter. Life. Culture and Technology vol. $1 \mathrm{n}^{\circ} 1$ (Wien 2013), PP. 5-20.

- «Utilidade - um Exercício Conceptual» in Revista Filosófica de Coimbra 42 (Coimbra 2012), pp 417-478.

- A Individuação da Sociedade Moderna, Coimbra University Press / Imprensa da Universidade de Coimbra, 2011. 